\title{
Preparation of Cinnarizine Oral Lyophilizates
}

\author{
Rasha K. Dhahir ${ }^{1}$, Myasar Al-Kotaji ${ }^{1,2}$ \\ ${ }^{1}$ Department of Pharmaceutics, College of Pharmacy, University of Mosul, Mosul, Iraq. \\ ${ }^{2}$ Department of Pharmaceutics, College of Pharmacy, Ninevah University, Mosul, Iraq. \\ Corresponding author:: rasha.kh@uomosul.edu.iq,
}

$\frac{\text { Received }}{15-07-2021} \quad \underline{\text { Accepted }}$

\section{ABSTRACT}

Background: Orally disintegrating tablets (ODTs) have gained an increasing interest in the pharmaceutical industry for the last years. Several technologies have been sophisticated for ODTs to improve patient compliance. In the present work, an attempt has been made to formulate and evaluate cinnarizine, a drug for motion sickness, in an easy to administer, rapid disintegrated dosage form (oral lyophilizates with enhanced disintegration and dissolution profile and consequent potential improvement in bioavailability.

Materials and Methods: Cinnarizine oral lyophilizates were prepared by dispersing the drug in an aqueous solution of mannitol, hydroxypropyl methyl cellulose, and glycine. Different formulations were prepared by freeze-drying (lyophilisation) technique. The effect of concentration of mannitol, hydroxypropyl methyl cellulose, and freezing time on the lyophilizates characteristics was investigated. The drug-excipient interaction was investigated as well.

Results: The resulting cinnarizine oral lyophilizates showed an enhanced disintegration $(27.5 \pm 3.53 \mathrm{sec}$ to $56 \pm 12.73 \mathrm{sec})$ and enhanced dissolution profile $(25.09 \%$ to $44.7 \%$ after two minutes). The infrared spectroscopic studies showed no drug-excipient interactions. Furthermore, increasing the concentration of mannitol, increasing the concentration of hydroxypropyl methyl cellulose and duplication of the duration of freezing time had a negative influence on the disintegration and dissolution properties of the resulting lyophilizates.

Conclusion: Cinnarizine oral lyophilizates were successfully prepared and resulted in a rapid disintegration, high dissolution profile, with stable characteristics and without noticeable drugexcipient interaction.

Keywords: Cinnarizine, oral lyophilizates, freeze-drying, Orally disintegrating tablets.

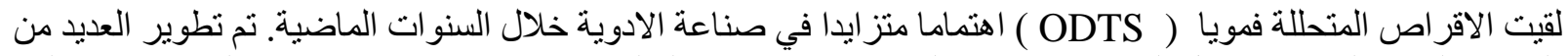

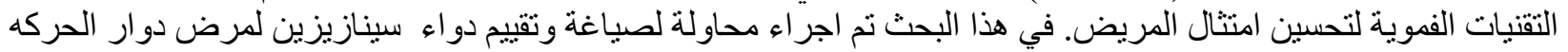

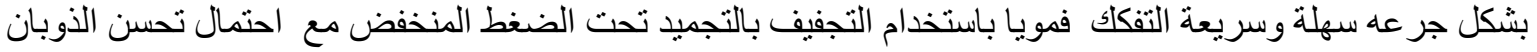

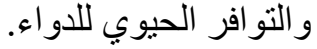

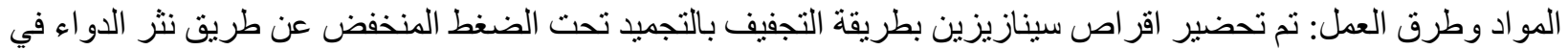

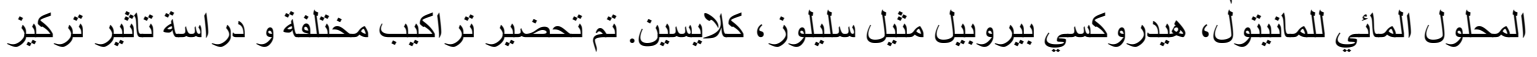
المانيتول، و هيدروكسي بروبيل مثيل سليلوز ، ووقت التجمد على خصائص التر اكيب ـ تم فحص تفاعل الاشكال الدو ائية ايضا. 


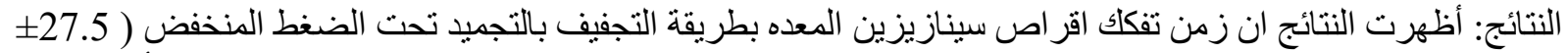

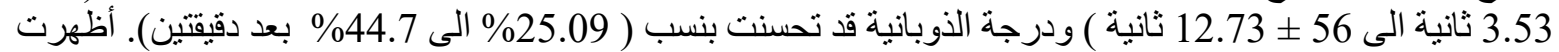

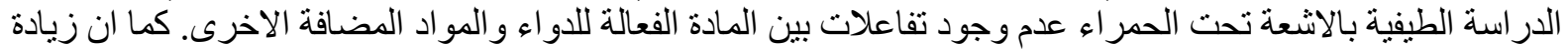

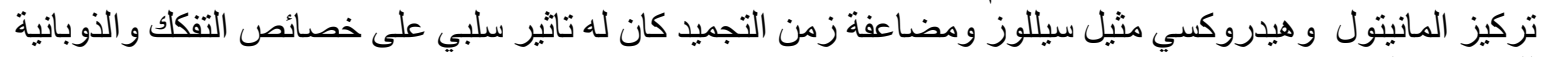

$$
\begin{aligned}
& \text { للمركبات الناتجة. }
\end{aligned}
$$

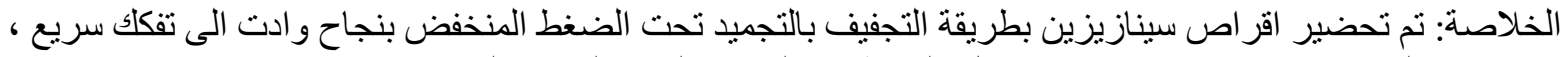

$$
\begin{aligned}
& \text { وذوبانية عالية ، وخصائص ثابتة وبدون تفاعل ملحوظ بين الدواء و المواد الغير فعاله. } \\
& \text { الكلمات المفتاحية: سيناريزين ، اقر اص فمويه معده بطريقة التجفيف بالتجميد تحت الضغط المنخفض ، تجفيف بالتجميد تحت } \\
& \text { الضغط المنخفض ، اقر اصنئن متحللة فمويا. }
\end{aligned}
$$

\section{INTRODUCTION}

According to the World Health Organization's reports on Global Health and Aging, there would be an increase in the population aged 65 or older from an estimated 0.5 billion in 2010 to nearly 1.5 billion in $2050 .{ }^{1}$ Difficulty in swallowing is an important problem in orally administered drugs in solid dosage form for children and elderly patient. ${ }^{2}$ On the other hand, using of the liquid dosage form as an alternative has several limitations related to stability, storage, transportation and packaging. ${ }^{3}$

For this reason, pharmaceutical industry has formulated orally disintegrating tablets (ODTs) which combine the advantages of both solid and liquid formulations. In addition, the bioavailability of a drug in this dosage form can be significantly improved due to its pre-gastric absorption before reaching the stomach. ${ }^{4}$ ODT disintegrates rapidly in the mouth which aids in rapid dissolution, improves the drug absorption, and accelerates its onset of action. ${ }^{5}$ An enhancement of the dissolution rates of water-insoluble drugs is one of the most challenging tasks of drug development because the enhanced dissolution rates can improve drug oral bioavailability. ${ }^{6}$

The first ODT approved by the food and drug administration (FDA) in 1996 was Zydis ${ }^{\circledR}$, which was prepared by the lyophilization method. ${ }^{5}$ Oral lyophilizates are defined according to European
Pharmacopoeia as "solid preparations intended either to be placed in the mouth or to be dispersed or dissolved in water before administration". 7 In the lyophilization process, the solvent is removed from the frozen solution or suspension of a drug and excipients under low temperature. This results in a light weight, highly porous tablet in which the drug would be in the amorphous state rather than a crystalline state that results in faster disintegration and dissolution rate. Examples of techniques based on lyophilization are Zydis $\AA$, Lyoc $\AA$, and NanoCrystal ${ }^{\mathrm{TM}}$ technologies. ${ }^{8}$

Lyophilization consists of three stages: first, the freezing stage which results in the transforming of water into ice that is separated from solute and other components by super-cooling. The temperature should be below that of glass transition temperature and eutectic temperature for amorphous and crystalline compounds, respectively. ${ }^{9}$ The second stage is the primary drying in which the chamber pressure is reduced below the equilibrium vapor pressure of ice and the shelf temperature is elevated. Finally, the secondary drying stage, which relies on temperature elevation above that of the primary drying to reduce the residual water to an acceptable level. ${ }^{10}$

Cinnarizine was first synthesized by Janssen Pharmaceutical in $1955 .{ }^{11}$ It is a histamine $\mathrm{H}_{1}$-receptor antagonist, used for the treatment of motion sickness, vertigo, and 
vomiting. Cinnarizine belongs to the biopharmaceutical classification system (BCS) class II, therefore, the drug dissolution is the limiting step for its absorption. ${ }^{12}$

Cinnarizine ODT was prepared by various methods like direct compression using super disintegrants ${ }^{4}$, and by effervescent and sublimation methods. ${ }^{13}$ The aim of this study is to develop new ODTs of cinnarizine using the lyophilization method.

\section{MATERIALS AND METHODS}

Cinnarizine powder was purchased from Apollo Healthcare Resources, Singapore. DMannitol powder was supplied from Scharlau, Spain. Hydroxy propyl methyl cellulose (HPMC) was taken from Ashland Industries Europe GMBH. Glycine 99\% was provided by Korea. Hydrochloric acid was supplied from Scharlau, Spain.

\section{Preparation of cinnarizine oral lyophilizates}

Four different formulations of cinnarizine oral lyophilizates $(25 \mathrm{mg}$ ) were prepared, the composition of the different formulations is presented in table one. Mannitol was used as a matrix former, along with hydroxypropyl methyl cellulose E5 (HPMC E5) as a cellulose binder, while glycine was used to form a porous, strong, and elegant cake. Glycine can act as a disintegration accelerant as well. ${ }^{14}$ A solution of HPMC E5 in water was prepared and stirred using a magnetic stirrer until a clear solution was obtained. Mannitol and glycine were added to the HPMC solution while stirring. An accurately weighed amount of cinnarizine was dispersed in the excipient mixture to yield the final percentage $(6.25 \%)$. A specific volume of the resulting dispersion was poured into each pocket of the tablet blister with a diameter of $13 \mathrm{~mm}$ and a depth of $3 \mathrm{~mm}$. The tablet blister packs were covered with aluminum foil with multiple punctures, and frozen at $-72^{\circ} \mathrm{C}$ in a deep freezer, then placed in a lyophilizer (ALPHA 1-4 LD plus, CHRIST LCG), with a condenser temperature of $-55^{\circ} \mathrm{C}$ and pressure of 0.088 mbar for $24 \mathrm{hr} .^{15}$

Evaluation of cinnarizine oral lyophilizates

Hardness (crushing strength)

Hardness determines the ability of a tablet to resist mechanical shocks while handling. ${ }^{16}$ From each formulation, 10 tablets were taken randomly and tested by tablet breaking force tester-USP (electrolab, India). The hardness was measured in Newton $(\mathrm{N})$, and represented as mean \pm standard deviation.

\section{Disintegration test}

Disintegration time for cinnarizine oral lyophilizates was detected using disintegration tester-3 USP, (electrolab, India), $900 \mathrm{ml}$ of distilled water was used ( $\left.37^{\circ} \mathrm{C} \pm 0.5\right) .{ }^{6,16}$ The complete disintegration time of the tablet with no palpable mass remaining in the apparatus was measured. ${ }^{17}$ The disintegration test was also performed on the marketed cinnarizine conventional tablet (Stugeron ${ }^{\circledR} 25 \mathrm{mg}$ tablet), to be compared with that of the best-prepared formulation of cinnarizine oral lyophilizates.

\section{Dissolution test}

A dissolution test for cinnarizine oral lyophilizates was conducted using dissolution test apparatus II (Pharma test, PTDT7, Germany) at a speed of $50 \mathrm{rpm}$. The dissolution medium was $0.1 \mathrm{~N} \mathrm{HCl}(\mathrm{pH} 1.2)$ in a volume of $900 \mathrm{ml}, 5 \mathrm{ml}$ of the medium was aspirated at different time intervals $(1,2$, $4,6,8,10,15,20,25$, and 30 minutes) and replaced by the same volume of fresh drugfree dissolution medium. The withdrawn samples were filtered through a $0.45 \mu \mathrm{m}$ filter, diluted and the dissolved drug was analyzed at $254 \mathrm{~nm}$ by UV spectrophotometer. ${ }^{17}$

Fourier transforms infrared (FTIR) studies 
The pure cinnarizine drug powder and the main other ingredients were subjected to IR analysis, either alone or in combinations as a physical mixture that represented the same actual ratios of the ingredients that present in the best formulation of the prepared cinnarizine oral lyophilizates. Thermo Mattson IR 300-spectrophotometer, USA, was utilized for the analysis, using potassium bromide disc and the scanning range was $500-4000 \mathrm{~cm}^{-1} .18$

\section{Statistical analysis}

Results are expressed as mean \pm standard deviation. Student pair t-test and ANOVA were utilized for statistical analysis, the difference was considered to be statistically significant when $\mathrm{P}<0.05$.

\section{RESULTS AND DISCUSSION}

\section{A. Effect of the concentration of the binder (HPMC E5) on hardness}

There was an increase in the hardness of the formulations in the rank of Lyoph 4> Lyoph 3> Lyoph 2> Lyoph1, table 2, figure 2.

In order to determine the effect of HPMC on the characteristics of cinnarizine oral lyophilizates, different formulas were prepared. It could be recognized that increasing the percentage of HPMC from 2\% to $3 \%$ (when $40 \%$ of mannitol was used in formulas: Lyoph 1 and Lyoph 2) did not exhibit a significant increase in the hardness of the tablets $(\mathrm{P}<0.05)$.

when $50 \%$ of mannitol was used (Lyoph 3 and Lyoph 4) the hardness was significantly increased when HPMC was increased $(\mathrm{P}<0.05)$. This could be attributed to the higher binding capacity at higher binder concentration $^{19}$, see figure 2 .

B. Effect of the concentration of the bulking agent (mannitol) on the hardness
It is interesting to note that the hardness of the tablets increased with increasing the concentration of mannitol in the formulas 3 and 4 (50\% of mannitol) when compared with that of formula 1 and $2(\mathrm{P}=0.008$ and $\mathrm{P}=0.001$ respectively), see figure 2 . Since mannitol has the affinity to crystallize from the frozen aqueous preparation, it results in an elegant cake with the required hardness at higher concentrations. ${ }^{20}$ This is inconsistent with the results founded by Safar et al (2011) who prepared new oral lyophilizates of diclofenac sodium using mannitol. ${ }^{15}$

\section{Disintegration test}

The results of the disintegration test of cinnarizine oral lyophlizates revealed that there was a prolongation in the disintegration time of the formulations in the rank of Lyoph 4> Lyoph 3> Lyoph 2> Lyoph1>, see table 2 and figure 2 .

The disintegration time of the different formulas of cinnarizine oral lyophilizates was in the range of $(27.5 \pm 3.53 \mathrm{sec}$ to $56 \pm 12.73$ $\mathrm{sec}$ ), which was within the pharmacopoeial limits of ODTs. ${ }^{7}$ However, for Stugeron ${ }^{\circledR} 25$ $\mathrm{mg}$ tablets, the disintegration time was relatively long $(312 \pm 4.32 \mathrm{sec})$. The disintegration time of cinnarizine oral lyophilizates was affected by the concentration of both the binder and the bulking agent as follows:

Increasing the concentration of the binder from $2 \%$ to $3 \%$ resulted in the prolongation of the disintegration time. However, this effect was significant $(\mathrm{P}<0.05)$ in formulas prepared with a higher percentage of mannitol (50\%). These results are correlated with the results of the hardness test of the lyophilizates, where increasing the concentration of the cellulose binder resulted in increasing the hardness as illustrated in figure 2. This may be due to higher binding capacity at higher binder concentration. These results are in agreement with the results obtained by Ahmed et al (2013) who 
studied, in a factorial design, the effects of different variables on the development and optimization of lyophilized orally disintegrating tablets of anti-inflammatory drug, nimesulide. ${ }^{19}$

Concerning the effect of different concentrations of mannitol, the results that are presented in figure 2 indicated that there was a prolongation in the disintegration time with increasing the concentration of mannitol from $40 \%$ to $50 \%$. This result is in agreement with the results obtained by Safar et al (2011) who reported an increase in the disintegration time when using a high concentration of mannitol. ${ }^{15}$

\section{Dissolution test}

The percentage of cinnarizine released from oral lyophlizates after 2 minutes was in the range $(25.09 \pm 3.22 \%$ to $44.75 \pm 5.67 \%)$ while it was $8.75 \pm 2.15 \%$ for Stugeron ${ }^{\circledR} 25$ $\mathrm{mg}$ tablet as illustrated in figure 2 and table 2. The rate and extent of drug dissolution from the prepared ODTs were greatly enhanced compared to the commercial tablets which may be due to the increased surface area, and wettability which facilitate tablet break down. $^{21}$ In addition, this enhanced dissolution could be due to the solubilizing effect of the highly water-soluble carrier materials that were used such as mannitol and glycine which are freely soluble in water, also HPMC can be dissolved in cold water and results in a colloidal solution. ${ }^{22}$

Effect of the bulking agent (mannitol) and the binder (HPMC E5) on the percentage of drug release

The effect of the bulking agent (mannitol) and the binder (HPMC E5) appears clearly in figure 2. Both of these affect the dissolution of the drug. However, increasing the concentration of mannitol from $40 \%$ to $50 \%$ resulted in the reduction of the percentage of cinnarizine released from the tablet. This reduction in the drug released was more pronounced when $3 \%$ of HPMC E5 was used in the formulations $(\mathrm{P}<0.0001)$ compared to that of $2 \%$ of HPMC $(\mathrm{P}=0.028)$. These findings were in accordance with the results of the disintegration test. The negative effect of the higher concentration of mannitol and HPMC on the drug release might due to the formation of harder tablets with a slower disintegration time.

The profound effect of the concentration of HPMC on the percentage of released cinnarizine is not in accordance with the results of another study conducted by Ahmed et al (2013). They found that the concentration of the cellulose binder had a clear effect on the disintegration time of ODTs of nimesulide but statistically it had no significant effect on the percentage of the released drug. However, they have used maltodextrin as a matrix former. ${ }^{19}$

Effect of freezing time on hardness, disintegration, and dissolution properties of the tablet

The effect of freezing time on different parameters of the lyophilized tablet was examined and illustrated in table 3 . The main drawback of the lyophilization technique is a long time of the process, therefore it is beneficial to examine the impact of the duration of freezing time on the properties of the finished product. The results demonstrated that freezing for $24 \mathrm{hr}$ is better than freezing for $48 \mathrm{hr}$. It is clear that there is a higher percentage of the drug released after 2 minutes for the formula Lyoph $2(44.75 \pm 5.67 \%)$ when compared with Lyoph 2x (30.89 $\pm 3.98 \%)$, $(\mathrm{P}=0.0006)$, as illustrated in figure 4 . This might be attributed to the greater hardness of the tablets that remained for $48 \mathrm{~h}$ under freezing in case of Lyoph $2 \mathrm{x}$, which affect negatively on the disintegration and dissolution time (figure 3). 
Fourier transforms infrared (FTIR) studies The FTIR studies revealed no detected chemical interaction between cinnarizine and all other excipients in the formula (mannitol, HPMC E5, and glycine). Figure 6. shows that there are no extra peaks or shift in peaks appeared when comparing IR of cinnarizine alone $^{23}$ (figure 6a), mannitol alone (figure 6b), HPMC E5 alone (figure 6c), glycine alone (figure 6d), with the IR chart of the physical mixture of cinnarizine and mannitol (figure 6e), cinnarizine and HPMC E5 (figure $6 f$ ), and cinnarizine and glycine (figure $6 \mathrm{~g}$ ). There is a weak physical interaction between the base drug-mannitol, base drug -HPMC, and the base drug-glycine.

\section{CONCLUSION}

Lyophilizate can be considered as a new dosage form. Its number in the market is increasing and there is a need to investigate the potential drugs to be formulated as in such dosage form. Cinnarizine tablet is available years ago, however, there is a need to formulate this drug in a rapidly disintegrating tablet to achieve a higher absorption rate and a shorter onset of action. This work succeeded in manufacturing of cinnarizine oral lyophilizates. Mannitol was chosen as a filler while HPMC E5 was used as binder and Glycine as disintegrant accelerator. The suitable freezing time was 24 hours rather than 48 hours and the lyophilisate product demonstrated rapid release and good stability. In addition, the lyophilisate did not show signs of possible chemical interactions between the different ingredients.

\section{ACKNOWLEDGMENTS}

We are very thankful to the Kurdish Institution for Strategic Studies and Scientific Research in Sulaymaniyah for their cooperation and permission to use their facilities. Thanks as well to the College of Pharmacy, University of Mosul.

Table 1: Different formulations of cinnarizine oral lyophilizates

\begin{tabular}{|l|l|l|l|l|l|}
\hline $\begin{array}{l}\text { Ingredients } \\
(\mathbf{w} / \mathbf{v}) \%\end{array}$ & Role of each ingredient & Lyoph 1 & Lyoph 2 & Lyoph 3 & Lyoph 4 \\
\hline Cinnarizine & Active drug & 6.25 & 6.25 & 6.25 & 6.25 \\
\hline Mannitol & Matrix former & 40 & 40 & 50 & 50 \\
\hline HPMC E5 & Binder & 2 & 3 & 2 & 3 \\
\hline Glycine & Disintegration accelerant & 0.8 & 0.8 & 0.8 & 0.8 \\
\hline
\end{tabular}


Table 2: Different evaluations of cinnarizine oral lyophilizates and the marketed cinnarizine conventional tablets (Stugeron ${ }^{\circledR} 25 \mathrm{mg}$ )

\begin{tabular}{|l|l|l|l|l|}
\hline $\begin{array}{l}\text { Formulation } \\
\text { type }\end{array}$ & $\begin{array}{l}\text { Hardness } \\
(\mathbf{N})\end{array}$ & $\begin{array}{l}\text { Disintegration } \\
\text { time* }(\mathbf{s e c})\end{array}$ & $\begin{array}{l}\text { \% Cinnarizine } \\
\text { released after 2 } \\
\text { minutes* }\end{array}$ & $\begin{array}{l}\text { Cinnarizine } \\
\text { content** }(\%)\end{array}$ \\
\hline Lyoph 1 & $25.6 \pm 1.05$ & $27.5 \pm 3.53$ & $38.79 \pm 2.10$ & $98.25 \pm 4.50$ \\
\hline Lyoph 2 & $27.1 \pm 1.72$ & $32.5 \pm 6.36$ & $44.75 \pm 5.67$ & $99.06 \pm 7.15$ \\
\hline Lyoph 3 & $31.9 \pm 2.03$ & $43 \pm 1.4$ & $33.78 \pm 4.32$ & $100.6 \pm 1.41$ \\
\hline Lyoph 4 & $37.9 \pm 1.57$ & $56 \pm 12.73$ & $25.09 \pm 3.22$ & $95.01 \pm 3.22$ \\
\hline $\begin{array}{l}\text { Stugeron }{ }^{\circledR} 25 \mathrm{mg} \\
\text { tablet }\end{array}$ & $108.1 \pm 0.5$ & $312 \pm 4.32$ & $8.75 \pm 2.15$ & $92.29 \pm 1.40$ \\
\hline
\end{tabular}

*Data are expressed as mean \pm S.D, $n=6$

**Data are expressed as mean \pm S.D, $\mathrm{n}=3$

Table 3: Effect of preparation conditions on the tablet hardness, disintegration time, and percentage of the drug release

\begin{tabular}{|l|l|l|l|l|}
\hline $\begin{array}{l}\text { Formulation } \\
\text { type }\end{array}$ & $\begin{array}{l}\text { Duration of } \\
\text { sample freezing in } \\
\text { deep freezer }\end{array}$ & $\begin{array}{l}\text { Hardness** } \\
(\mathrm{N})\end{array}$ & $\begin{array}{l}\text { Disintegration } \\
\text { time* }(\mathrm{sec})\end{array}$ & $\begin{array}{l}\text { \% Drug release } \\
\text { after 2 minute* }\end{array}$ \\
\hline Lyoph 2 & $24 \mathrm{hr}$ freezing & $27.1 \pm 1.72$ & $32.5 \pm 6.36$ & $44.75 \pm 5.67$ \\
\hline Lyoph 2x & $48 \mathrm{hr}$ freezing & $35.23 \pm 2.5$ & $45 \pm 7.07$ & $30.89 \pm 3.98$ \\
\hline
\end{tabular}

*Data are expressed as mean \pm S.D, $n=6$

**Data are expressed as mean \pm S.D, $\mathrm{n}=3$ 


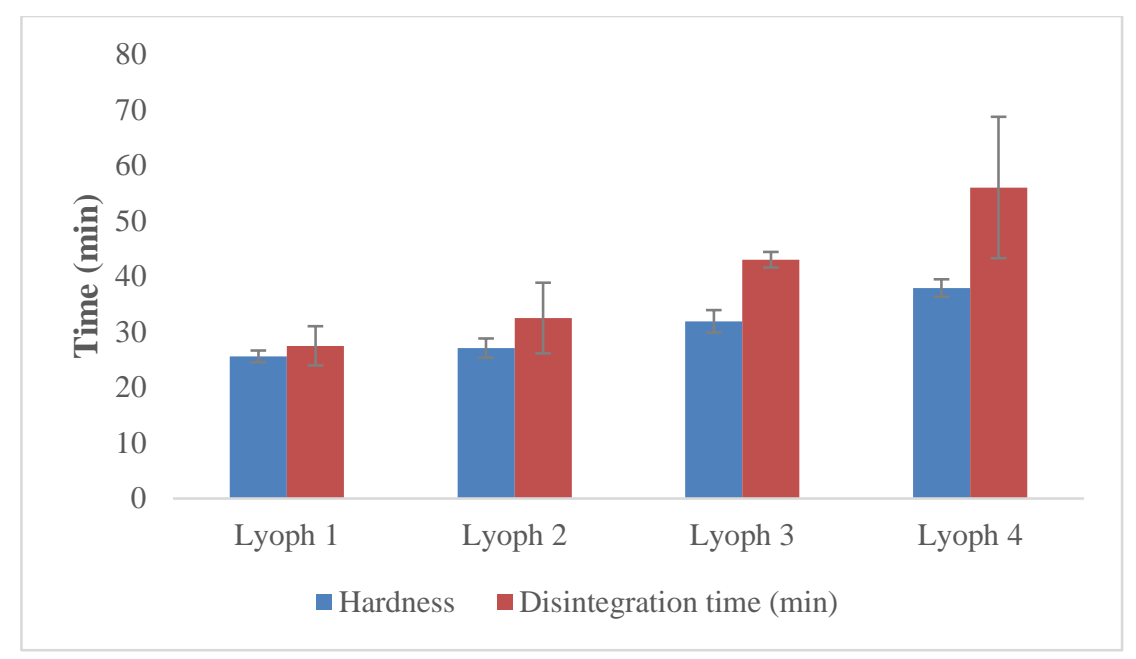

Figure 1: The relation between hardness and disintegration time of the different formulations of cinnarizine oral lyophilizates

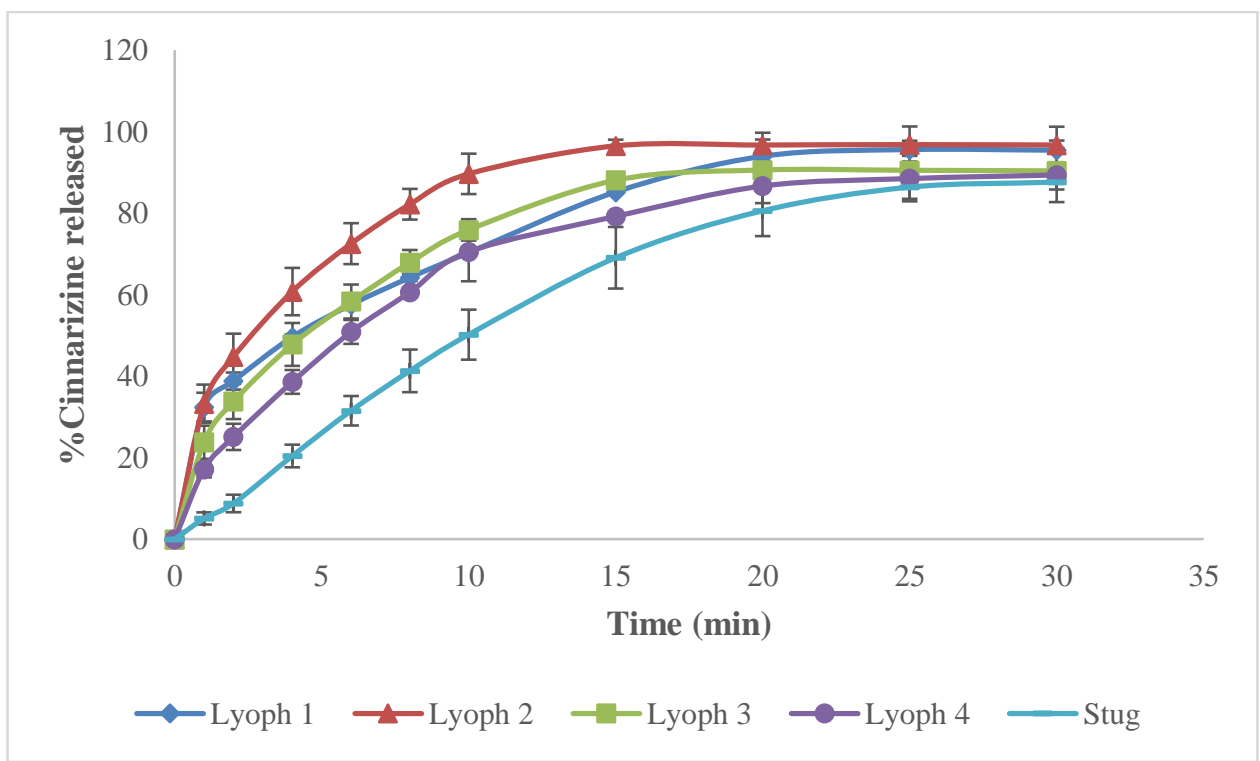

* Stug: Stugeron ${ }^{\circledR} 25 \mathrm{mg}$ tablets

Figure 2: Percentage of the drug release of the prepared cinnarizine oral lyophilizates (Lyoph 1, Lyoph 2, Lyoph 3 and Lyoph 4) and the marketed one. 


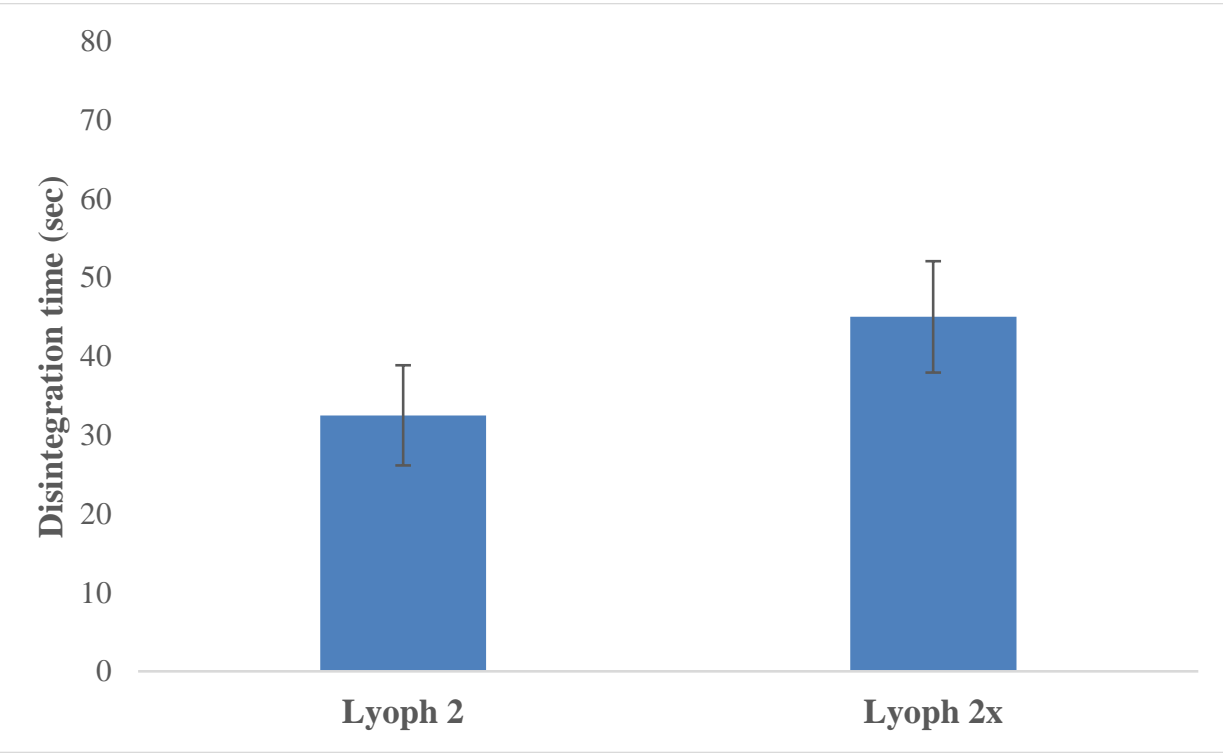

Figure 3: Comparison of the disintegration time of the prepared cinnarizine oral lyophilizates under different experimental conditions

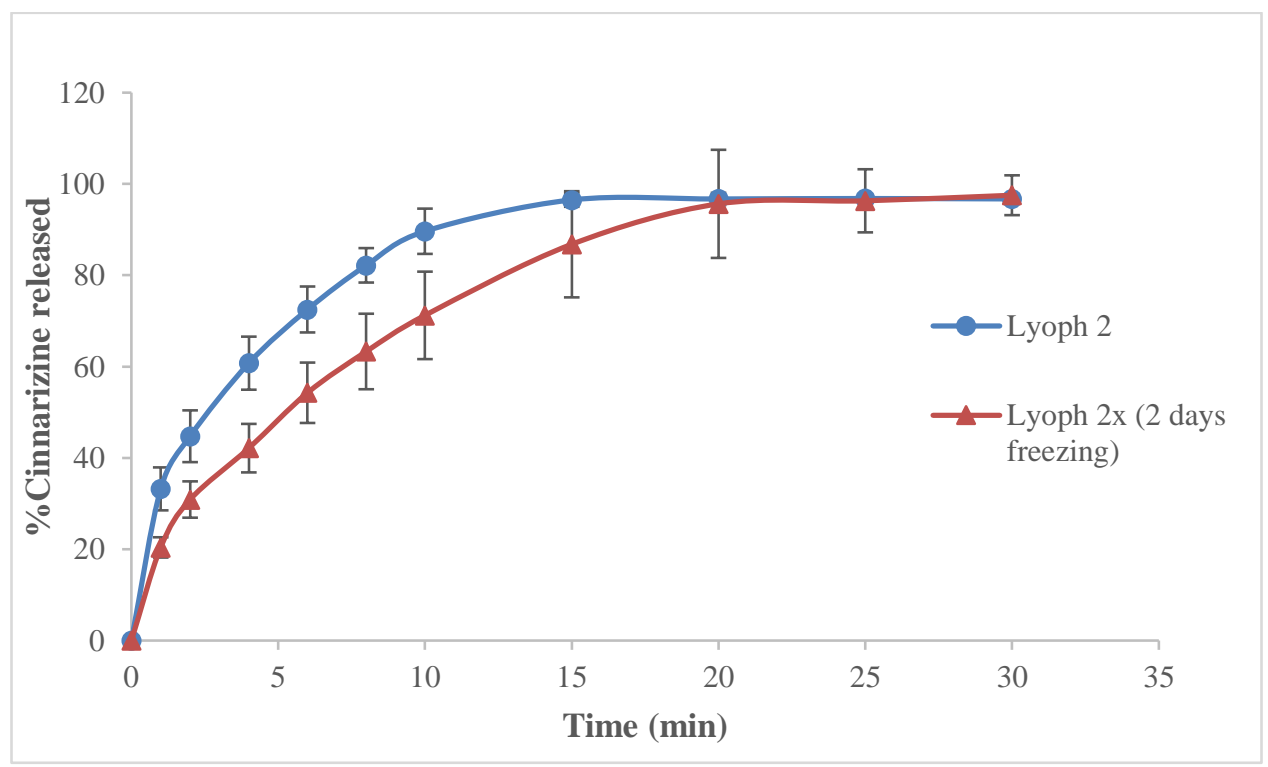

Figure 4: Comparison of the percentage of the drug release of the prepared cinnarizine oral lyophilizates (Lyoph 2 and Lyoph 2x) under different preparation conditions (freezing time). 


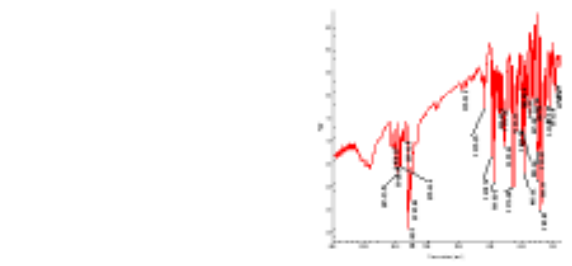

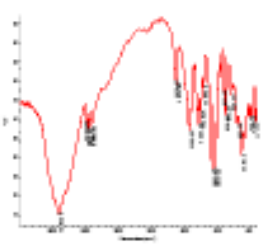

(b)

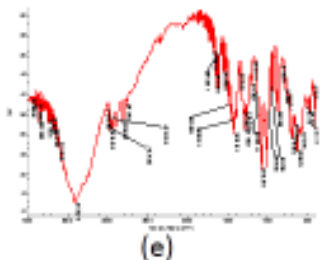

(e)

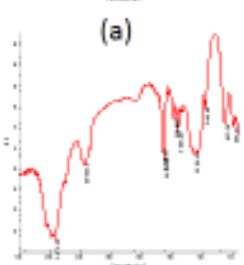

(c)

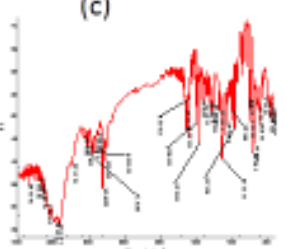

(f)

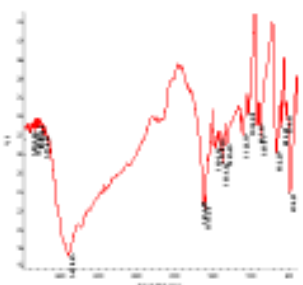

(d)

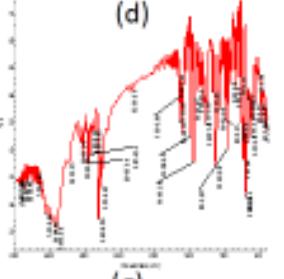

(g)

Figure 5: (a) The FTIR spectrum of cinnarizine alone, (b) mannitol alone, (c) HPMC E5 alone, (d) glycine alone, (e) cinnarizine and mannitol, (f) cinnarizine and HPMC E5, (g) cinnarizine and glycine.

\section{REFERENCES}

1. World Health Organization, Global health and aging, https://www.who.int/ageing/ publications/global_health.pdf, (2019), Accessed date: 31 July 2019.

2. Bpac New Zealand, Encouraging Children to Swallow Tablets or Capsules, (2019) https://bpac.org.nz/Supplement/2014/ September/docs/pillswallowing_articl e.pdf, Accessed date: 31 July 2019.

3. Stoltenberg I, Breitkreutz J. Orally disintegrating mini-tablets ( ODMTs ) - A novel solid oral dosage form for paediatric use. Eur.J.Pharm. Biopharm. 2011;78:462-9.

4. Al-dhahir RK, Alkotaji M.
Formulation of orally disintegrating tablets of cinnarizine by using direct compression method. Int $\mathbf{J}$ Appl Pharm. 2019;11.

5. Akdag Y, Gulsun T, Izat N, Cetin M, Oner L, Sahin S.Characterization and comparison of deferasirox fast disintegrating tablets prepared by direct compression and lyophilization methods. Journal of Drug Delivery Science and Technology. J Drug Deliv Sci Technol [Internet]. 2020;57:101760.

6. Al-nima AM, Alkotaji M. Preparation and evaluation of meloxicam solid disperssion by solvent evapuration method. Int.Res.J.Pharm. 2014;5.

7. The European Pharmacopoeia. 9th ed. 
Council of Europe, Strasbourg; 2017.

8. Almukainzi M, Araujo GLB, Löbenberg R. Orally disintegrating dosage forms. $\mathbf{J}$ Pharm Investig. 2018;0:0.

9. Shivanand A, Mukhopadhayaya S. A review on lyophilization: a technique to improve stability of hygroscopic, thermolabile substances. Pharmatutor. $2017 ; 5$.

10. Kawasaki H, Shimanouchi T, Kimura Y. A review: recent development of optimization of lyophilization process. Journal of chemistry. 2019; 2019.

11. Janssen, P.A.J., US Patent no. 2882 271, 1959.

12. Kumar CA, Swetha B, Jyoshna B, Meghana A, Mounika A. Formulation and evaluation of oral disintegrating tablets of cinnarizine. IJARMPS. 2019;8:7-13.

13. Gupta MM, Patel V. Formulation and evaluation oral disperssible tablet of cinnarizine. J Drug Deliv Ther. 2013;3:12-7.

14. Rowe RC, editor. Handbook of pharmaceutical excipients (6th ed). London: APhA, (PhP) Pharmaceutical Press; 2009.

15. Safar R, Abdelwahed W, Chehna MF, Degobert G, Fessi H. Preparation and characterization of new oral lyophilizates containing a non steroidal anti inflammatory drug. Int $\mathbf{J}$ Pharm Pharm Sci. 2011;3:108-14.

16. R LPD, Konde A. Formulation and evaluation of lovastatin tablets by using liquid solid compact technique.
GSCBPS. 2019;08:139-55.

17. Patel BP, Patel JK, Rajput GC, Thakor RS. Formulation and evaluation of mouth dissolving tablets of cinnarizine. Indian $\mathrm{J}$ Pharm Sci. 2010;72:522-5.

18. Shaikh RH, Jamadar MJ, Patil AD, Tamboli SM. Formulation and in-vitro evaluation of antiemetic orodispersible combination tablets of domperidone and cinnerizine by using various superdisintegrants. Pharmatutor. 2015;3:49-59.

19. Ahmed IS, Shamma RN, Shoukri RA. Development and optimization of lyophilized orally disintegrating tablets using factorial design. Pharm Dev Technol. 2013;18:935-43.

20. Kim AI, Akers MJ, Nail SL. The physical state of mannitol after freezedrying: Effects of mannitol concentration, freezing rate, and a noncrystallizing cosolute. J Pharm Sci. 1998;87:931-5.

21. Venkata Ramana Reddy S, Dondeti S, Manavalan R, Sreekanth J. Comparison of lyophilization and compression technique of risperidone oral disintegrating tablets. Der Pharma Chem. 2010;2:172-84.

22. BP. British Pharmacopoeia. London, Stationary office; 2017.

23. Yeo LK, Olusanya TOB, Chaw CS, Elkordy AA. Brief effect of a small hydrophobic drug (Cinnarizine) on the physicochemical characterisation of niosomes produced by thin-film hydration and microfluidic methods. Pharmaceutics. 2018;10. 